\title{
BROADCASTING IMPLEMENTATION
}

IN ISLAMIC LAW PERSPECTIVE

\section{IMPLEMENTASI PENYIARAN DALAM PERSPEKTIF HUKUM ISLAM}

\author{
Fachri Fachrudin ${ }^{1}$ \\ ${ }^{1}$ Prodi Ahwal Al-Syakhshyiah STAI Al Hidayah Bogor
}

\begin{abstract}
ABSTRAC
Broadcasting is a part of communication, while communication is an inseparable part of human life because all our steps are always complete with communication. In Islam, da'wah can be interpreted as a communication process (tabligh) that can be done individually or in masses. This paper will discuss more about where is broadcasting in the perspective of Islamic law. While the research method used in this study is Qualitative Content Analysis. The results of this study state that the Islamic religion has solved the problem of broadcasting through the rules of da'wah. The principle that underlies the information broadcast must have the authenticity and validity of the source and its truth and be in accordance with the mashlahat values that are in accordance with maqashid al shari'at.
\end{abstract}

Keywords: broadcasting, law, propaganda, Islamic law.

\begin{abstract}
ABSTRAK
Penyiaran adalah bagian dari komunikasi, sedangkan komunikasi merupakan bagian yang tidak terpisahkan dalam kehidupan manusia karena segala gerak langkah kita selalu disertai dengan komunikasi. Dalam Islam, dakwah dapat diartikan sebagai proses komunikasi (tabligh) yang dapat dilakukan secara individual maupun massal. Tulisan ini hendak menggali sejauh mana penyiaran dalam perspektif hukum Islam. Sedangkan metode penelitian yang digunakan dalam penelitian ini adalah Qualitative content analysi. Hasil Penelitian ini menyatakan bahwa Agama Islam sudah mengatur masalah penyiaran melalui aturan-aturan dakwah. Prinsip yang mendasar adalah informasi yang disiarkan haruslah memiliki otentisitas dan validitas sumber dan kebenarannya serta didasarkan pada nilai-nilai mashlahat yang seiring dengan maqashid al syari'at.
\end{abstract}

Kata kunci: penyiaran, hokum, dakwah, hokum Islam. 


\section{A. PENDAHULUAN}

Sebuah teori mengatakan bahwa manusia kerap kali didefinisikan sebagai makhluk sosial, makhluk yang berfikir atau makhluk yang berpolitik. ${ }^{1}$ Artinya manusia merupakan makhluk yang membutuhkan antara satu dengan yang lainnya. Dinamis menjadi karakter yang inhern pada diri manusia sehingga dapat beradaptasi dari waktu ke waktu. Keinginan untuk mengembangkan diri tersebut membutuhkan informasi dan komunikasi dalam interaksi di antara mereka sehingga hal tersebut menjadi proses sosial. Hubungan timbal balik antara kehidupan yang terjadi di dunia ini dengan media massa sudah berlangsung sejak lama. Era komunikasi dunia mengalami kemajuan yang sangat pesat dan cepat. Dengan adanya perkembangan teknologi dalam berkomunikasi mempermudah

\footnotetext{
${ }^{1}$ Banyak yang menyatakan bahwa teori ini dinisbatkan kepada Ibnu Khaldun (732-806 H.) sebagaimana perkataan beliau dalam $A l$ Muqaddimah halaman 41:

الاجتماع الإنساني ضروري ويعبر الحكماء عن هذا

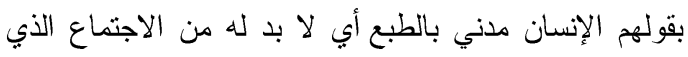
هو المدينة في اصطلاحهم وهو معنى العمران.
}

Akan tetapi Ibnu Al-Qayyim (691-749 H.) telah lebih dulu mengeluarkan teori ini dalam kitabnya Zad Al-Ma'ad (3/11) dengan perkataanya;

و الانسان مدني بالطبع لا يعيش الا مع بني جنسه ومن لم يقر

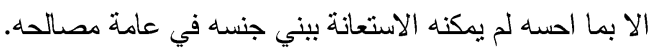

penyampaian informasi dari satu tempat ke tempat lain di berbagai belahan dunia. Kemajuan dan kemunduran komunikasi tentunya memberikan dampak positif maupun negatif terhadap kehidupan manusia baik sosial, politik, ekonomi, dan ketahanan suatu negara.

Teori media massa dan masyarakat mengatakan bahwa penyiaran memiliki sejumlah asumsi untuk membentuk masyarakat, dalam arti penyiaran memiliki efek yang berbahaya sekaligus menular bagi masyarakat, penyiaran memiliki kekuatan untuk mempengaruhi pola pikir rata-rata audiensnya, dan rata-rata orang yang terpengaruh oleh media ini dikarenakan ia mengalami keterputusan dengan institusi sosial yang sebelumnya justru melindungi dari efek negatif media. ${ }^{2}$ Tulisan ini hendak menggali sejauh mana implementasi penyiaran dalam perspektif hukum Islam. Pembicaraan tentang permasalahan penyiaran dalam hukum Islam penulis kategorikan dalam kajian fikih siyasah dusturiyah yang lingkup pembicaraannya tentang aturan, perilaku, dan keyakinan yang absolut, hingga melahirkan konsep penyiaran

${ }^{2}$ Muhammad Mufid. (2007). Komunikasi dan Regulasi Penyiaran. Jakarta: Kencana Prenada Media Group. hlm. 19. 
yang benar sebagai medium dalam membentuk individu dan masyarakat yang sesuai dengan tujuan syar'i dan undang-undang yang berlaku.

Teori yang digunakan dalam penelitian ini adalah teori mashlahāt mursalāh (istishlāh), ${ }^{3}$ yaitu apa yang dipandang baik oleh akal, sejalan dengan tujuan syara' dalam menetapkan hukum, namun tidak ada petunjuk syariat yag memperhitungkannya dan tidak ada pula petunjuk syāra' yang menolaknya. Jumhur ulama sepakat untuk menggunakan mashlahah mu'tabarah sebagaimana mereka juga menolak untuk mashlahah al-mulghāh.

Sedangkan metode penelitian yang digunakan dalam penelitian ini adalah qualitative content analysis adalah salah satu dari beberapa metode kualitatif yang yang digunakan untuk menganalisis data dan menginterpretasikan maknanya, (Schreier, 2012). ${ }^{4}$ Jenis penelitian ini

3 Al-Ghazali dalam kitab Al-Mustashfā merumuskan mashlahah mursalah sebagai berikut:

ما لم يشهر له من الثرع بالبطلان و لا بلاعتبار نص معين "Apa-apa (mashlahah) yang tidak ada bukti bagiya dari syara' dalam bentuk nash tertentu yang membatalkannya dan tidak ada yang memerhatikannya".

4 Satu Elo, et.al. (2014). Qualitative Content Analysis: A Focus on Trustworthiness. SAGE Open January-March, 4. hlm. 1. adalah penelitian kualitatif document study. Jenis penelitian ini lebih menitikberatkan pada analisis teks pada konteksnya yang dideskripsikan secara sistematis berdasarkan data yang sudah diklasifikasi berdasarkan objek kajian. Untuk memperoleh hasil yang sesuai dengan rumusan masalah penulis menggunakan pendekatan yuridis normative, ${ }^{5}$ pendekatan ini mirip dengan research library. ${ }^{6}$

\section{B. PEMBAHASAN}

Mulai munculnya penyiaran (الإعلام) adalah semenjak adanya kebutuhan untuk menyampaikan berita, dengan kata lain adalah sejak terbentuknya kehidupan sosial bagi manusia. Penyiaran ini merupakan satu kebutuhan manusia yang tidak bisa terlepas darinya, dan kita dapat mendapati awal permulaan penciptaan makhluk, ketika Allah S.W.T. menciptakan Nabi Adam alaihissalam. dan mengajarkannya segala nama serta memerintahkan Adam untuk

${ }^{5}$ Zulfi Diane Zaini. (2011). Implementasi Pendekatan Yuridis Normatif dan Pendekatan Normatif Sosiologis dalam Penelitian Ilmu Hukum. Journal Article Pranata Hukum. hlm. 119.

${ }^{6}$ Abdi Mirzaqon T dan Budi Purwoko. Library Research of The Basic Theory and Practice of Expressive Writing Counseling. Jurnal Nasional. hlm. 3. 
memberitahukan hal itu kepada para malaikat. Allah S.W.T. berfirman:

"Dan Dia mengajarkan kepada Adam nama-nama (bendabenda) seluruhnya, kemudian mengemukakannya kepada para malaikat lalu berfirman: "Sebutkanlah kepada-Ku nama benda-benda itu jika kamu mamang benar orang-orang yang benar!" Mereka menjawab: "Maha suci Engkau, tidak ada yang Kami ketahui selain dari apa yang telah Engkau ajarkan kepada kami; Sesungguhnya Engkaulah yang Maha mengetahui lagi Maha Bijaksana." (Q.S. Al-Baqarah [2]: 31-32).

Ayat ini mengandung faedah, di antarnya adalah bahwa manusia sesungguhnya telah mengenal penyiaran dari awal hidupnya, dia terbiasa degannya dengan menggunakan fitrahnya yang telah diilhamkan dan diajarkan Allah S.W.T. kepada manusia. Pada mula adanya manusia, muncul metode-metode ungkapan secara berkesinambungan tentang cara berfikir dan gagasannya, cara bagaiman memberitakan dari segala yang dijangkau oleh beragam dinamika serta perubahannya. Ketika seorang manusia mendapat kesulitan bahasa untuk mengungkapkan aspirasinya, dia mulai menggunakan gerakan dan suara, seperti isyarat, menyalakan api, menabuh beduk, dan lain sebagainya dari zaman dahulu kala yang sebagian masih digunakan sampai era kita ini. Sebagaimana kita juga dengan mudah dapat memperhatikan dimensi sosial dalam kehidupan manusia, yang telah diciptakan agar saling mengenal satu sama lainnya, saling membagi, merasa nyaman dengan kehadiran yang lainnya, saling ingin mengetahui kabar maingmasing, dan memperhatikan kondisi masing-masing. Allah S.W.T. telah mengisyaratkan hal ini dalam FirmanNya:

"Hai manusia, sesungguhnya Kami menciptakan kamu dari seorang laki-laki dan seorang perempuan dan menjadikan kamu berbangsa-bangsa dan bersuku-suku supaya kamu saling kenal-mengenal. Sesungguhnya orang yang paling mulia di antara kamu di sisi Allah ialah orang yang paling taqwa di antara kamu. Sesungguhnya Allah Maha mengetahui lagi Maha Mengenal." (Q.S. Al-Hujurat [49]: 13)

Allah S.W.T. menciptakan mereka agar saling mengenal, saling berinteraksi, bukan untuk saling membanggakan diri dan saling memutus hubungan dengan yang lainnya. 


\section{Asas Penyiaran dalam Islam}

Penyiaran adalah bagian dari komunikasi, sedangkan komunikasi merupakan bagian yang tidak terpisahkan dalam kehidupan manusia karena segala gerak langkah kita selalu disertai dengan komunikasi, selain itu penyiaran juga bersifat mengarahkan menumbuh-kembangkan, mencegah atau memproteksi, sehingga tidak berlebihan bila Islam dinyatakan sebagai agama yang menumbuhkembangkan. ${ }^{7}$

Dalam Islam, dakwah dapat diartikan sebagai proses komunikasi (tabligh) yang dapat dilakukan secara individual maupun massal.

Islam sebagai agama dakwah mewajibkan umatnya untuk melakukan internalisasi, transmisi, difusi, transformasi, dan aktualisasi syari'at Islam dengan metode dan penyiaran dengan tetap mengacu kepada Al-Qur'an dan sunnah Rasulullah kepada mad' $\bar{u}$ (umat manusia). Allah S.W.T. berfirman:

\section{"Katakanlah: 'Inilah jalan (agama)ku, aku dan orang-orang yang mengi-kutiku mengajak (kalian) kepada Allah dengan}

${ }^{7}$ Muhammad Sarbini dan Rahendra Maya. (2019). Gagasan Pendidikan Anti Jahiliyah dan Implementasinya. Edukasi Islami: Jurnal Pendidikan Islam, 08(01). hlm. 2. hujjah yang nyata, Maha suci Allah, dan aku tidak termasuk orang-orang yang musyrik." (Q.S. Yusuf [12]: 108)

Berdasarkan ayat tersebut, banyak ulama yang bersintesa bahwa dakwah memiliki empat rukun yang tidak dapat dipisahkan antara satu dengan yang lainnya, yaitu: ${ }^{8}$ Tema atau materi dakwah (maudhu'' al-da'wah); Objek dakwah atau audiens (al-mad'ū). Subjek, pengemban dakwah atau

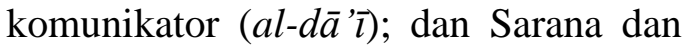
metode dakwah (wasā'il al-da'wah wa asālībuhā). Komunikasi dakwah memiliki unsur-unsur di dalamnya yaitu sumber komunikasi, komunikator, pesan komunikasi, penyiaran komunikasi, komunikan, tujuan, dan akibat. Penyiaran komunikasi dapat bersifat maknawi ataupun materi. Penyiaran salah satunya menjadi penyiaran komunikasi massa. ${ }^{9}$ Untuk itu

8 'Abd Al-Karīm Zaidān. (2005). Ushūl AlDa'wah. Beirut: Mu'assasah Al-Risālah Nāsyirūn. hlm. 9; dan Sa'̄̄d bin 'Alī bin Wahf Al-Qahthānī. (1994). Muqawwimāt Al-Dā'iyah Al-Nājīh fi Dhau' Al-Kitāb wa Al-Sunnah: Mafhūm wa Nazhar wa Tathbiq. Saudi Arabia: tp. hlm. 86-87. Sedangkan Dr. Al-Bayanuni, mensintesakan hanya tiga rukun saja, minus rukun yang keempat, karena include dalam rukun pertama: Muhammad Al-Fath Al-Bayanuni. (1993). dalam Al-Madhal Ila 'Ilmi Al-Da'wah, Beirut: Mu'asasah AlRisalah. hlm. 152.

9 Kustandi Suhandang. (2013). Ilmu Dakwah. Bandung: PT Remaja Rosdakarya. 
penyiaran dalam Islam harus diasaskan pada tiga asas utama, yaitu tauhid, asas syariah, dan asas akhlak. Ketiga-tiga asas ini berperana dalam membentuk pribadi mulia masyarakan dan praktisi penyiaran yang mencerminkan normanorma Islam serta sesuai undangundang, membentuk dasar penyiaran berdasarkan Islam yang selaras dengan Islam, serta menjamin penyampaian informasi yang benar dan tepat.

Asas tauhid selalu menjadi landasan utama dan tertuang dalam visi dan misi setiap lembaga penyiaran yang ada. Asas tauhid menjadi barometer penilaian dalam setiap program siaran dan informasi yang akan disampaikan, bahwa setiap siaran dan informasi yang disampaikan tidak hanya akan menimbulkan efek duniawi akan tetapi bernilai ukhrawi. Sedangkan asas syariah menjadikan Penyiaran dalam hal ini sebagai penyiaran massa untuk menyampaikan ide, pesan, dan nilainilai Islam kepada masyarakat luas. Maka, dakwah adalah cara agama Islam dalam melakukan penyiaran dengan berbagai macam sarananya. Arti lebih

hlm. 19-24, bandingkan dengan Muhammad AlFath Al-Bayanuni. (1993). Al-Madhal Ila 'Ilmi Al-Da'wah. Beirut: Mu'asasah Al-Risalah. hlm. 318. jauhnya, penyiaran adalah bentuk lain dari dakwah Islam dalam merealisasikan tujuan-tujuan syari’ah.

Terdapat sedikit perbedaan di kalangan pakar hukum dan ulama Islam terkait penentuan asas dan prinsip syari'at atau hukum Islam. Mereka tidak bersepakat dengan penggunaan kata "asas" untuk merujuk kepada "dasar, alas, dan fondamen pembentukan dan penerapan hukum Islam". Walaupun dan kamus bahasa Inggri kata "asas" memiliki makna yang sama dengan kata "principle". ${ }^{10}$ Namun demikian penulis berpendapat hal tersebut bukanlah termasuk ke dalam perbedaan yang kontradiktif, akan tetapi lebih kepada perbedaan keberagaman akan makna. Sehingga bisa dikatakan satu dengan yang lainnya saling menguatkan.

\section{Tujuan Penyiaran dalam Islam}

Islam mewajibkan umatnya untuk mengekspresikan pendapatnya dan melakukan kritik terhadap kesalahan yang terjadi. Inilah konsep amar makruf nahi munkar yang dikenal dalam Islam. Amr makruf nahyi munkar merupakan kewajiban bagi tiap individu muslim,

10 Jeje Zaenudin. (2015). Metode dan Strategi Penerapan Syari'at Islam di Indonesia. Jakarta: Pembela Islam Penyiaran. hlm. 32. 
apa pun profesinya. Dengan demikian, ajaran Islam selangkah lebih maju dibanding undang-undang lain produk manusia, yang hanya menjadikan mengkritik sebagai hak, bukan kewajiban. Pasal 19 Deklarasi Universal HAM (Universal Declaration of Human Rights, 1948) menyatakan, "Setiap orang berhak atas kebebasan beropini dan berekspresi. Hak ini meliputi kebebasan untuk memiliki opini tanpa intervensi, serta untuk mencari, menerima, dan mengungkapkan informasi serta gagasan melalui penyiaran apapun dan tidak terikat pada garis berpendapat". 11

Tentunya dalam amr ma'ruf nahyi munkar pun harus mengacu kepada kaidah daf'u al-mafāsid wa jalbu almashālih dengan segala kaidah turunannya. Metode penyampaian yang bijaksana, tepat sasaran, terpercaya, mudah difahami, santun, baik, dan straight to the point. ${ }^{12}$ Semua dilakukan mengarah kepada tujuan perubahan sosial yang dikehendaki Islam, yaitu

11 Faris Khoirul Anam, http://www. republika.co.id/Jurnalislamia, diposting tanggal 7 Februari 2015.

${ }^{12}$ Q.S. Thaha: 43-44, QS. An-Nisa: 9 dan 63, Al-Israa: 23 dan 28, An-Nissa ayat 5 dan 8, Al-Baqarah Ayat 235 dan 263, serta Al-Ahzab Ayat 32 . terbentuknya khairu ummah (umat terbaik) yang beriman kepada Allah, hingga terbentuk budaya mengajak kepada kebaikan dan mencegah kepada kemunkaran. $^{13}$ Arah dan tujuan penyiaran sejatinya adalah upaya merealisasikan teori kredo pada setiap pribadi muslim. ${ }^{14}$ Mengeluarkan manusia dari penyembahan kepada selain-Nya menuju penyembahan hanya kepada Allah semata, dari kesempitan dunia kepada keluasan dunia dan akhirat, serta dari penyelewengan agama sebelumnya kepada keadilan Islam. $^{15}$

\section{Fungsi dan Karakter Penyiaran dalam Islam}

Penyiaran memiliki enam fungsi esensial, di antaranya yaitu sebagai berikut:

a. Ikhbariyyah, yaitu menyampaikan berita kejadian dan kasus-kasus penting, yang dapat diikuti oleh masyarakat baik perkembangan serta implikasinya. Isi beritanya hampir dapat membentuk persentasi yang sangat dominan saat ini yang mestiya dapat

${ }^{13}$ Q.S. Ali Imran Ayat 104 dan 110.

14 Juhaya S Praja. (1993). Filsafat Hukum Islam. Islamic Law. hlm. 133.

${ }^{15}$ Sayyid Qutb. (2002). Tafsir fi Dzilalli Al-Qur'an. Jakarta: Gema Insani Press. hlm. 47. 
menyajikan kejadian-kejadian dengan teliti, detil, dan jujur agar mendapatkan pengahargaan dari masyarakat.

b. Ijtima'iyyah, merupakan hal yang memperhatikan masyarakat dan fenomena kejadian dan meningkatkan hubungan kedua belah pihak serta mempererat ikatan sosial.

c. Tarbawiyyah tsaqafiyyah, hal ini mengandung pengajaran keterampilan baru dan menambah wawasan serta maklumat. Adapun pendidikan pengetahuan publik bertujuan untuk menambah wawasan individu dengan penyiaran bukan dengan sarana pendidikan akademik. Pendidikan secara umum ini terjadi pada ruang lingkup sosial bagi individu, baik itu secara spontan, terencana, terprogram maupun dengan sengaja.

\section{d. Tarfihiyyah tarwihiyyah,} merupakan sebuah penyiaran yang diperuntukan sebagai hiburan.

e. Taswiqiyyah, Adalah sebagai sarana pemasaran yang mencakup iklan, sepanduk dari produk bisnis tertentu.

\section{f. Iqna'iyyah taujihiyyah}

Merupakan sebuah kegiatan untuk merumuskan dan mengarahkan yang bertujuan untuk membenntuk sikap, haluan, dan prilaku, atau penguatan. Semua itu, kareana khawatir terpengaruh oleh propaganda penyiaran lain yang kontradiktif. Selama materi penyiaran yang disuguhkan relevan dengan bahasa publik, maka pengaruhnya pun semakin kuat.

Secara umum tidak jauh berbeda dengan fungsi penyiaran lainnya, kecuali pada deskripsi yang disesuaikan dengan aturan syariah dan nilai-nilai masayarakat Islam. Ada beberapa fungsi tambahan dalam penyiaran Islam, di antaranya:
a. Berfungsi sebagai penyiaran dakwah

$\begin{array}{lr}\text { Sebagaimana Islam } & \text { sangat } \\ \text { berupaya untuk pertama } & \text { kalinya } \\ \text { menyebarkan keyakinan } & \text { tauhid }\end{array}$ yang bertujuan untuk mengajak manusia kepada penghambaan yang murni kepada Allah semata, mennyingkirkan segala bentuk kesyirikan, membongkar kebusukan para thaaghut, membebaskan manusia dari 
keyakinan dusta yang diada-adakan oleh musuh-musuh Islam, menyingkap keyakinan yang batil dan sesat, dan berkonsentrasi untuk mengajak pihak lain untuk memeluk agama Islam. ${ }^{16}$

b. Sebagai Penyiaran Pemberitaan

Sebagaimana berfungsi untuk menyampaikan kabar, maklumat, dan peristiwa. Memuat problematika kaum muslimin, mennyuguhkannya, menelaahanya, dan mempersembahkan dengan solusi-solusi yang relevan sesuai dengan pandangan atau konsep Islam dengan memperhatikan minoritas kaum muslimin di seluruh penjuru dunia. Hal ini merupakan salah satu fungsi dari penyiaran, khususnya penyiaran Islam yang sangat dominan dan vital saat ini karena tanpa adanya penyiaran kita sangat sulit untuk mendapatkan informasi secara cepat dan tepat dari berbagai penjuru dunia. Hanya saja zaman sekarang ada sedikit kelemahan dari penyiaran, tidak terlepas dari penyiaran Islam sebagai sarana

16 Adul Qadir Thasy. (1990). Idha'at Haula Al-I'lam Al-Islami. Qatar: Micistay Fawqaf and Islamic Affers. hlm. 17. pemberitaan itu. Yaitu ditandai dengan adanya beberapa berita yang kadang seolah dibuat-buat dan didramatisir yang menyebabkan isi beritanya cacat dan sulit untuk diterima kebenarannya.

c. Fungsi praktis dan edukasi

Berfungsi juga untuk meningkatkan perhatian masyarakat terhadap ketinggian akal, nurani, dan tingkah laku mereka, dan juga membekali mereka dengan ilmu sayr'i dan yang lainnya dari ragam ilmu yang bermanfaat, dan juga menyebarluaskan pemahaman Islam berikut pokok-pokonya yang luhur dan nilai-nilainya yang tinggi, serta menanamkan makna-makna edukasi dan akhlak yang diajarkan oleh syariah Islam guna membina generasi beriman yang mampu untuk bangkit dengan mengemban risalah (pesan dakwah) Islam.

d. Fungsi sosial dan pengembangan

Bagi aspek sosial dan pengembagannya, penyiaran Islam berfungsi untuk membangun individu Islami, seimbang, inovatif, dan handal serta membangun masyarakat yang komitmen dan paripurna, memperkuat rasa 
kemanusiaan terhadap orang lain dengan menebar ruh perdamaian, kasih sayang, saling mengenal, saling mencintai, hidup berdampingan antar kaum muslimin, dan menguatkan ikatan sosial antar mereka, serta membela kaum lemah. Adapun memperhatikan problematika kaum muslimin merupakan dasar yang agung, maka siapa saja yang tidak memperhatikan urusan kaum muslimin, dia bukan bagian dari mereka, menguatkan bahwa harga diri manusia harus dijaga, kebebasan individu harus terjamin, dan melindungi masyarakat Islam dari pengaruh kuat masayakat Barat dengan membeberkan peradaban Barat dengan konsepnya yang bertentangan dengan kemanusiaan, yang berdasarkan egoisme dan sekularisme yang timbul karena mereka memisahkan antara agama dari seluruh aspek kehidupan, memisahkan pula akhlak dari pendidikan. Walaupun mereka berupaya mengkalim kesuksesannya, namun realita membuktikan bertumpuknya permasalahan-permasalahan psikis dan moral bahkan politik dan ekonomi disebabkan konsepkonsep ini. Hal ini juga berusaha untuk menajamkan konsep pengembangan yang komprehensif di masyarakat pada sela-sela bertambahnya produktifitas.

e. Fungsi layanan umum

Penyiaran Islam tidak mengesampingkan layanan umum yang dibuktikan oleh adanya ramalan cuaca, jadwal waktu shalat atau adzan, dan konseling hukum, kedokteran dan keluarga.

f. Fungsi hiburan

Penyiaran Islam memperhatikan juga sisi hiburan yang sesuai dengan aturan syariat. Karena hiburan bukan sesuatu yang ditolak dalam pandangan penyiaran Islam. Hal ini jauh berbeda antara hiburan yang layak dan beradab serta tidak bertentangan dengan nilai-nilai Islam dengan hiburan yang merusak dan semua pihak mengeluhkannya. Maka dalam ini sudah barang tentu penyiaran Islam itu berfungsi sebagai sarana hiburan, dengan catatan selalu menyiarkan hiburan-hiburan yang sesuai dengan syari'at Islam dan 
menolak siaran hiburan yang dilarang dalam syari'at Islam. Dengan demikian, fungsi penyiaran Islam selaras dengan syari'at Islam yang dibawa oleh Nabi Muhammad Saw.

g. Fungsi promosi dan marketing Hampir sama dengan penyiaran masa lainnya, penyiaran massa Islam juga berfungsi untuk mempromosikan seluruh produk yang mubah dengan cara yang mubah pula, yang mampu mengembangkan serta menguatkan perekonomian Islam baik secara khusus maupun umum. Hal ini dilakukan demi mensejahterakan masyarakat pada umumnya, khususnya masyarakat Islam.

Karakter penyiaran Islam memiliki keunggulan dari penyiaran yang umum dengan beberapa keunggulan berikut ini:

a. Penyiaran akidah yang
berkomitmen dan berpesankan
dakwah

Ada sebuah ketentuan bahwa penyiaran Islam harus mencerminkan keyakinan Islam secara efektif dan signifikan, bukan sekedar slogan semata yang selalu diteriakan dan hanya menjadi peraturan saja, akan tetapi harus ada bukti yang nyata mengenai penyiaran Islam yang mencerminkan keyakinan Islamnya. Adapaun penyiaran Islam berkomitmen dengan akidah Islam pada setiap urusan kehidupan. Dia berkerja untuk menyebarluaskan akidah atau keyakinan tersebut dan menguatkan kesadaran tentangnya dan berhukum serta tunduk kepadanya dalam segala hal, dan ini telah ditegaskan dalam muktamar pertama tentang penyiaran Islam $^{17}$ yang termaktub dalam pasal pertama dalam piagamnya untuk berkomitmen: memperkuat keimanan dengan nilainilai dan pokok-pokok dasar akhlak Islam; Berupaya memyempurnakan kepribadian Islami; Menyuguhkan realita secara ikhlas dalam batasan etika Islam; serta menjelaskan hak-hak dan kewajiban-kewajibannya kepada pihak lain di atas pondasi kebebasan.

Penyiaran Islam memiliki pondasi, aturan syar'i, dan kaidahkaidah global yang bersandar dan bertolak darinya. Penyiaran haru memiliki komitmen dengan hal-hal berikut ini:

17 Yang diselenggarakan di Jakarta Indonesia pada bulan Syawal 1400 H/11 September 1980. 
a. Al-Tadqiq (mengedit dan meneliti) terhadap apa-apa yang disiarkan, disebarkan, dan yang disajikan. Dengan tujuan untuk melindungi karakter, kesucian, nilai umat Islam dari efek negatif, dan bahaya yang mengintainya.

b. Menyampaikan pesannya dengan cara yang lembut, dalam rangka menjaga citra (reputasi baik) profesi, dan dengan etika Islami. Maka jangan sampai menggunakan kata-kata yang tajam, tidak menyebarkan gambar-gambar asusila, tidak merendahkan dengan hinaan, menjatuhkan tokoh, melontarkan tuduhan, cacian, hinaan yang memicu perseteruan, dan tidak menyebarkan isu-isu serta segala yang mmicu konflik.

c. Tidak menyebarkan berita terkait segala hal yang menyinggung khalayak atau yang menyebabkan kerusakan moral, atau yang memotivasi kepada perbuatan kriminal, kekerasan, bunuh diri, mengintimidasi, atau membangkitkan syahwat baik secara langsung maupun tidak langsung. d. Tidak menyebarkan iklan komersial yang mengandung penyimpangan akhlak dan nilai-nilai Islami.

Penyiaran Islam berkomitmen dengan ide umat Islam yang bersih dan terbebas dari iklan yang sempit, fanatisme ras, fanatisme kabilah, dan membangkitkan tekad-tekad untuk melawan keterbelakangan pada setiap bidangnya, dan mewujudkan pengembangan yang komprehensif yang mengantarkan umat Islam untuk menggapai keemasan, ketinggian, dan kejayaannya. ${ }^{18}$

Adapun komitmen dan menjaga aturan syariat memberikan ruang kebebasan bagi penyiaran Islam yang jauh dari mudahanah dan keberpihakan, penyiaran dalam Islam tidak akan pernah menjadi alat yang dimanfaatkan oleh penguasa untuk berbuat sewenangwenang terhadap umat manusia, atau mempermainkan mereka seperti yang terjadi di rezim atau sistem diktator yang menjadikan penyiaran sebagai mesin untuk menekan dan memaksakan kehendak.

${ }^{18}$ Muhammad Sayyid Memaulana. (1403 H). Al-Mas'uliyyah Al-I'lamiyyah. Kairo: Maktabah Al-Khaniji. hlm. 355-357. 


\section{Kebebasan Penyiaran Terjamin Tetapi Bertanggung jawab}

Sejatinya kebebasan penyiaran (informasi) Islami tidak terlepas kepada pandangan Islam itu sendiri tetang konsep kebebasan. Sungguh Islam sangat menghargai kebebasan berekspresi, mengakuianya, dan bahkan memotivasinya. Hal ini bukanlah hasil dari buah fikir manusia semata, bukan juga hasil perjuangan pribadi atau kelompok untuk melawan para diktator yang sewenang-wenang, akan tetapi hal ini merupakan anugerah Ilahi sekaligus merupakan salah satu karakteristik dari keluhuran syariah Islam yang bersumber dari teks-teks syariah. ${ }^{19}$

Adapun sebuah kebebasan individu merupakan prinsip yang disepakati dari seorang manusia mampu berbuat di atas paksaan internal melalui keinginan, dan paksaan eksternal melalui tekanan dan kontrol, dan tidak mungkin kebebasan kelompok dapat menggantikan kebebasan individu seperti yang diklaim oleh ajaran Marxisme. Maka kebebasan kelompok pada realitanya adalah kebebasan sekelompok individu, karena

${ }^{19}$ Rabil Muhammad Thayibah. (1984). AlHuquq wa Al-Hurri Al-Siyasah fi Al-Syarah AlIslamiyah. Wasington: Ma'had Alili Al-Fikr AlIslami. hlm. 332. masyarakat atau kelompok yang bebas adalah masyarakat yang setiap individunya pun bebas pula, sedangkan kebebasan tidak timbul kecuali dari keimanan dengan keyakinan tauhid. ${ }^{20}$ Oleh karena itu, Nabi Saw menjadikan salah satu syarat menjadi penduduk yang sesungguhnya bagi seorang muslim dan ketergabungannya ke dalam satuan rakyat Islam adalah ucapan yang hak dan menampakkannya agar terealisasi di masyarakat tersebut. Dari Ubadah bin Shamit berkata:

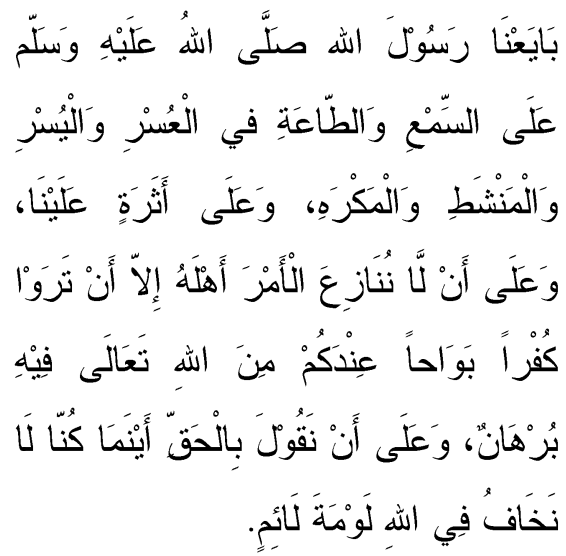

"Kami berbai'at kepada Rasulullah saw. untuk mendengar serta taat, baik dalam keadaan sulit ataupun mudah, juga dalam keadaan giat atau malas, juga agar kita semua lebih mengutamakan kepentingan orang lain dari diri sendiri. Selain itu pula supaya kita tidak merebut kekuasaan dari orang-orang yang berhak, kecuali jika kalian melihat

${ }^{20}$ Ibrahim Imam. (1985). Ushul Al-I'lam Al-Islami. Kairo: Dar Al-Fikri. hlm. 37. 
kekufuran yang nyata, berdasarkan dalil dari Allah. Dan agar kita semua berkata benar di mana saja kita berada, tidak takut untuk mengatakan hak itu akan celaan dari orang yang suka mencela." (H.R. Al-

\section{Bukhari dan Muslim).}

Sebagaimana Rasulullah S.A.W. menganggap bahwa jika sesesorang tidak mengungkapkan pendapatnya merupakan perkara yang tidak terpuji. Telah diriwayatkan dari Nabi dari Ibnu Hibban:

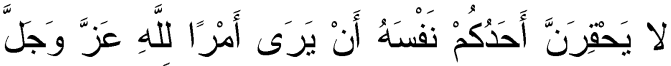

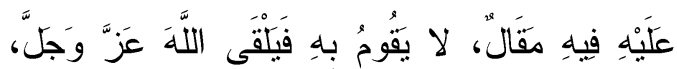

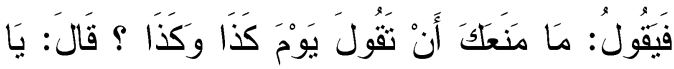

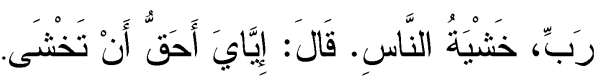
Nabi menegaskan perihal kebebasan penyiaran sampai hal terkait dengan pemerintah, dan beliau Saw menghitungnya sebagai salah satu dari bentuk jihad dan bahkan di antara bentuk jihad yang paling tinggi. Nabi bersabda:

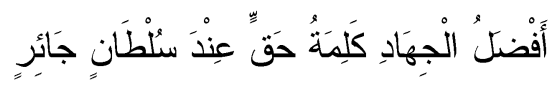

Banyak fakta sejarah yang mengaskan kebebasan Islam dan pembelaan terhadap hak sepanjang waktu, diantaranya; Di waktu perang Badar, ketika Nabi menempatkan para sahabatnya di tempat terdekat dengan air di lokasi Badar, datanglah kepada beliau seorang sahabat bernama AlHabab Ibnu Al-Mundzir dan berkata, "Wahai Rasulullah, bagaimanakah pendapat anda tentang posisi ini? Apakah posisi ini diwahyukan oleh Allah S.W.T. sehingga kita tidak boleh maju atau mundur? Ataukah ini hanya pendapat, siasat, dan taktik perang saja"? Beliau menjawab: "Ini hanya pendapat, siasat, dan taktik perang saja." Al-Habab ra mengatakan: "Wahai Rasulullah, posisi ini kurang tepat, bawalah orang-orang ini ke sumur yang paling dekat dengan posisi musuh. kita kuasai sumur itu lalu yang lainnya kita rusak. Kita membuat telaga besar lalu kita penuhi air. Kemudian baru kita perangi mereka, kita bisa minum sementara mereka tidak bisa." Rasulullah saw bersabda kepada AlHabab ra, "Engkau telah menyampaikan pendapat yang jitu." Rasulullah S.A.W. menyetujuinya dan melakukannya.

Ash-Shallabi berkata tentang pristiwa ini, "Mestinya setiap individu dalam komunitas mana saja menyampaikan pendapatnya, sampai pada kasus paling penting tanpa rasa takut atau khawatir dari kemarahan komandan tertinggi sekalipun, dan tidak takut akan diri dan hartanya dengan 
bersilang pendapat dengan komandan. Kebebasan ini yang langsung di bawah bimbingan Rasulullah S.A.W. kepada para sahabatnya, telah membuat komunitas mereka senantiasa mengambil faedah dari ide-ide yang valid, rasional, dan bijak. Walaupun dari orang yang tidak terlalu dikenal dan dari golongan atau pangkat biasa, karena tidak ada sedikitpun penghalang yang mengahalangi sampainya ide dari bawahan kepada komandannya."

Pada peristiwa Perang Uhud Nabi S.A.W. mengumpulkan para sahabatnya untuk mengajak bermusyawarah dengan mereka untuk tetap tinggal di Madinah dan memperkuat pertahanan atau keluar untuk menghadang musush. Adapun pendapat Nabi Saw adalah menetap di Madinah, dan beliau bersabda: "Kita dalam benteng yang kokoh..." AthThabari dan Ibnu Katsir berkata: Dan banyak dari kalangan sahabat yang menolak ide tersebut kecuali mereka keluar untuk mengahadang musuh, dan mayoritas mereka tidak ikut perang Badar, dan mereka mengetahui keunggulan kedudukan ahli Badar, ${ }^{21}$

21 Al-Hafidh Ibnu Katsir. (1988). AlBidayah wa Al-Nihayah. Bairut: Maktabah AlMa'arif, Juz 4. hlm. 14., dan Tarikh Al-Thabari, Juz 2. hlm. 60.
Ibnu Ishaq berkata; para sahabat bersikeras untuk memilih berhadapan langsung dengan musuh, sehingga Nabi S.A.W. masuk ke dalam rumahnya, maka para sahabat ada yang saling menyalahkan, mereka berkata: Nabi Allah menawarkan kepada kalian pendapat dan kalian manawarkan pendapat lain, maka wahai Hamzah pergilah dan katakanlah kepada nabi, "Pendapat kami tergantung pendapat engkau", maka Hamzah mendatangi nabi dan kemudian berkata, wahai Nabi, sesungguhnya para sahabat saling menyalahkan, mereka mengatakan, "Pendapat kami tergantung pendapat engkau”, maka Rasulullah Saw menjawab: "Sesungguhnya tidak layak bagi seorang Nabi yang bersama kaumnya untuk meletakkan senjatanya dan tidak berperang bersama kaumnya."22

Ash-Shallabi berkata: 'Sangat jelas bahwa Nabi biasa mendidik para sahabatnya dengan berterus terang dengan ide-ide mereka dalam musyawarah, walaupun sampai menyelisihi pendapatnya dalam perkataan yang tidak ada nash (teks)

22 Ibnu Hisyam. (t.t.). Al-Sirah AlNabawiyyah, Juz 2. Beirut: Dar Al-Fikri. hlm. 71. 
nya, untuk melatih mereka dalam berfikir dalam urusan umum, dan dalam hal menyelesaikan problematika keumatan, tidak ada guna bagi musyawarah tanpa kebebasan dalam berpendapat. $^{23}$

Dari beberapa penggalan pristiwa di atas, maka dapat disebutkan kerangka umum kebebasan berpendapat dalam Islam, yaitu sebagai berikut:

a. Bahwa kebebasan dalam Islam merupakan hak setiap manusia, tidak boleh diabaikan atau dihilangkan, karena hal tersebut merupakan prinsip sosial kemanusiaan dan merupakan syarat menuju kemajuan peradaban.

b. Menghormati orang lain, mengakui haknya dalam kebebasan berekspresi dan berpendapat dari ide-idenya, dan tidak memaksakannya. Allah S.W.T. berfirman dalam Surat Yunus Ayat 99:

"Dan jikalau Tuhanmu menghendaki, tentulah beriman semua orang yang di muka bumi seluruhnya. Maka apakah kamu (hendak) memaksa

${ }^{23}$ Ali Muhammad Al-Shallaby. (2005). AlSirah Al-Nabawiyyah wa tahlil Ahdats. Beirut: Dar Al-Ma'rifah. hlm. 476. $\begin{array}{lrr}\text { manusia supaya } & \text { mereka } \\ \text { menjadi orang-orang } & \text { yang } \\ \text { beriman semuanya." } & (\mathbf{Q . S} \\ \text { Yunus [10]: 99) } & \end{array}$

Dan Surat Al-Baqarah Ayat 256:

"Tidak ada paksaan untuk (memasuki) agama (Islam); sesungguhnya telah jelas jalan yang benar daripada jalan yang sesat...". (Q.S alBaqarah [2]: 256)

c. Bahwa dalam menasihat demi kebaikan umat merupakan amal yang mengandung nilai ibadah, tidak boleh bagi seseorang untuk menahan itu karena rasa takut dari mengungkapkan kalimat hak, walaupun sampai nyawa dan kebebasan menjadi taruhannya.

d. Tidak mengintimidasi dan menteror siapapun dari individu rakyat disebabkan karena pendapat yang dia yakini, baginya hal menuntut siapapun yang menentang kebebasannya tanpa melihat ketinggian jabatan yang dimilikinya.

e. Tidak ada seorang pun di masyarakat yang kebal dari kritikan.

Berdasarkan kerangka-kerangka ini, bisa membuat prinsip-prinsip kebebasan berekspresi dan 
berperpendapat dalam penyiaran islami sebagai berikut:

a. Penyiaran islami adalah penyiaran bebas dengan syarat tidak menimbulkan salah dalam menggunakan dan berlebih-lebihan dalam mengaplikasikan kebebasan sehingga menyebabkan penolakan terhadap hak, menyakiti jiwa atau pihak lain, melampaui batas dalam kebebasan individu dan masyarakat, atau melanggar syariat.

b. Kebebasan penyiaran terikat dengan keluhuran akhlak dan nilai. Maka Islam mengajarkan kepada sistem kepenyiaranannya untuk menjauhi kebebasan tanpa batas yang diekspos dari penyiaran Barat dan Timur yang memamerkan aurat, dipenuhi dengan pembeberan aib, isu-isu negatife, kata-kata, mengurusi privasi orang lain, dan mebuka rahasia. Allah berfirman dalam Surat An-Nur Ayat 19:

"Sesungguhnya orang-orang yang ingin agar (berita) perbuatan yang amat keji itu tersiar di kalangan orangorang yang beriman, bagi mereka azab yang pedih di dunia dan di akhirat. Dan Allah mengetahui, sedang, kamu tidak mengetahui." (Q.S An-Nur [24]: 19).
Para filosof telah mengetahui kerusakan yang ada di masyarakat Barat berupa kebebasan yang tidak ada batasan dan aturan. ${ }^{24}$ Maka bagi para aktifis penyiaran Islam harus menyelidiki, menverifikasi, dan berhatihati terkait data yang dinukil, karena data (maklumat) yang didasarkan pada dugaan adalah data yan yang tidak valid, dapat menggiring penyebarnya untuk membuat keputusan yang jauh dari kebenaran, karean berdasarkan dugaan dan prasangka. ${ }^{25}$ Allah S.W.T. berfirman dalam Surat Al-Hujurat Ayat 12, Al-Isra Ayat 36, dan Sabda Nabi Muhammad S.A.W.

$$
\text { كفى بالمر ء اثما ان بحدث بكل ما بسمع }
$$

Islam telah memperingatkan seluruh penyiarannya untuk tidak dimanfaatkan oleh para penguasa untuk menyanjung dan mengangkat-angkat mereka, karena dapat membodohi dan menipu masyarakat, atau dapat membantu mereka untuk menipu serta berlaku sewenang-wenang. Nabi bersabda dalam hadits yang diriwayatkan Ahmad:

${ }^{24}$ Salamah Muhammad Al-Balawi. Dauru Hurriyyah Al-Ta'bir fi Al-Izdihar Al-Hadhari. hlm. 447.

${ }^{25}$ Salamah Muhammad Al-Balawi. Dauru Hurriyyah Al-Ta'bir fi Al-Izdihar Al-Hadhari. hlm. 446. 


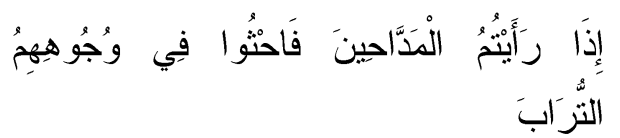

Umar Bin Al-Kahatthab ra ketika mendengar ada seorang pejabat waktu itu mengumpulkan para penyair untuk memujinya, maka Umar seketika memecatnya dan berkata: "Jika mereka telah menyanjungmu dengan apa adanya, maka engkau orang yang paling tahu, dan jika mereka menyanjungmu dengan yang tidak ada padamu, maka itu merupakan pemicu kedustaan dan kemunafikan, dan dapat membuatmu congkak."

Bahkan para pengganti (khalifah) Rasulullah Saw sangat bersemangat untuk menjelaskan kepada umat manusia kesalahan-kesalahan mereka, agar mereka menyadari dan merubahnya. Abu Bakr Ash-Shiddiq ra. berkata dalam pidato pertamanya setelah diangkat menjadi khalifah: "Wahai manusia, sesungguhnya aku diangkat untuk memimpin kalian dan aku bukan yang terbaik di antara kalian. Jika aku baik, maka bantulah aku dan jika aku berbuat buruk, maka luruskanlah aku." ${ }^{26}$ Umar ra. berkata; "Semoga Allah merahmati seseorang

${ }^{26}$ Al-Hafidh Ibnu Katsir. (1988). Juz 6. hlm. 397. yang memberitahukan kepadaku kekuranganku." Maka penyiaran Islam merupakan penyiaran yang penuh tanggung jawab. Adapun prinsip tanggung jawab di sini berlandaskan di atas prinsip individu, sosial, dan hukum.

Adapun prinsip individu maksudnya adalah seseorang mengontrol dan menperhitungkan dirinya dan dia memiliki kendali agama, seorang pegiat penyiaran betakwa kepada Allah dalam mewujudkan kebebasan berbicara dan berekspresi dan lebih ditekankan lagi ketika dia sadar bahwa kata-kata dalam penyiaran akan sampai kepada ribuan manusia dan bahkan jutaan manusia yang ada di dunia ini dan diterima oleh semua kalangan. Allah berfirman dalam Surat Qaf Ayat 18, Surat Al-An'am Ayat 3, dan Sabda Nabi Muhammad S.A.W. yang diriwayatkan oleh At-Tirmidzi:

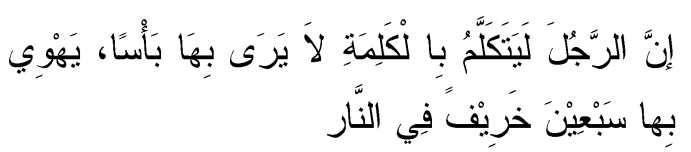

Seorang pegiat penyiaran Islam sebagai supervisor bagi dirinya baik dalam hal ucapan maupun tulisan. Prinsip sosial bahwa pengawasan masyarakat terhadap penyimpangan, isu-isu, dan hal-hal negatif lainnya dapat berpengauh terhadap kerja 
penyiaran itu sendiri. Dan pengawasan Islam terhadap hubungan kemasyarakatan dapat memperkuat rasa para pegiat penyiaran untuk lebih menghargai keyakinan dan nilai-nilai akhlak masyarakat setempat.

Dan prinsip qadha'i (peradilan hukum), dalam rangka menghargai pegiat penyiaran bukan berarti harus memberi perlindungan yang membuat dia bebas untuk berbicara sesuka hatinya. Seorang pegiat penyiaran adalah manusia biasa yang dikelilingi oleh rekan sejenisnya yang tidak luput dari kelemahan dan kelalaian. Oleh karena itu, Islam menetapkan untuk menanyakan para penggiat penyiaran tentang apa yang mereka keluarkan dari pemberitaan, mengingat bahwa di negara Islam tidak ada seorang pun yang kebal dari hukum dan bahkan para khlalifah sekalipun.

Dari pemaparan di atas bahwa Islam mengedepankan pengawasan individu yang muncul dari rasa murāqabah seorang muslim dari segala ucapan dan perbuatannya dan dia sadar bahwa semua itu akan dipertanggungjawabkan di hadapan Allah S.W.T. kecil atau besarnya. Jika jiwa individu mulai melemah dan dikalahkan oleh al-nafsu al-amārah bi $a l-s \bar{u}$ ', maka peran masyarakat saat itu dituntut untuk mengamankannya. Dan jika terus melampaui batas dan beranai untuk memanfaatkan penyiaran, maka di saat itu hukum bertindak untuk membersihkan dan meluruskan jiwanya dari perbuatan yang tidak layak baginya dan juga melindungi yang lainnya, masyarakat secara umum, dan semua syiar-syiar Islam dari tangan-tangan yang tidak bertanggung jawab akibat kelemahan penggiat dan lembaga penyiaran tersebut.

\section{Penyiaran Terbuka dan Proporsional}

Islam adalah agama yang memperlihatkan dirinya, keyakinannya, dan syariatnya kapan dan di mana saja. Oleh karena itu, penyiaran yang berorientasi kepada agama ini haruslah dibangun di atas keterbukaan. Keterbukaan ini menuntut sikap berani untuk mengungkapkan yang hak dan bersandarkan kepada kejujuran dan tidak takut celaan yang mencela. Maka penggiat penyiaran Islam jujur terhadap segala yang diterbitkannya yang tidak membutuhkan kode dan isyarat-isyarat, jelas dalam mengkritik dan meluruskan kekeliruan selama itu ditujukan untuk 
membela agama Allah dan mengatakan benar kepada yang benar dan membendung kebatilan, hal ini sama baik ditujukan kepada individu maupun kelompok. Jika keburukan itu datang dari orang yang terang-terangan memusuhi Islam dan dominasinya sudah menancap di penyiaran, maka ini memungkinkan untuk dijelaskan dengan sejelas-jelasnya, disingkap keburukannya dengan cara ilmiah serta objektif setelah berusaha dijelaskan dengan cara sindiran atau isyarat, sabagaimana metode Nabi Muhammad

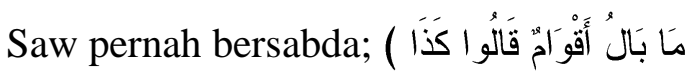

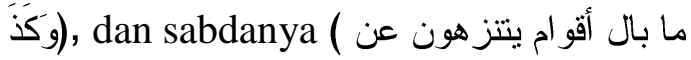
(أصنعه الثيء).

Penyiaran merupakan sarana pelurusan akhlak, maka keraguan dalam amr ma'ruf dan nahi munkar dapat menyebabkan tersebar uasnya kemungkaran dan hilangnya pesan dakwah. Meskipun dengan keberaniannya penyiaran haruslah bersikap proporsional dan seimbang, penyiaran harus menghargai pendapat yang masih mengedepankan objektifitas dalam berdialog dan menyampaikan serta menerima saran. Allah Ta'ala berfirman dalam Surat Al-Baqarah Ayat 111:

"Katakanlah: "Tunjukkanlah bukti kebenaranmu jika kamu adalah orang yang benar." (Q.S. Al-Baqarah [2]: 111).

Di antara bentuk keproporsionalan adalah meninggalkan perdebatan kusir, karena Islam mencela perdebatan seperti itu walaupun berada di paihak yang benar, dikarenakan dapat menimbulkan permusuhan, kerusakan, dan kekacauan yang tidak diinginkan kesudahannya. Sebagaimana Nabi Muhammad S.A.W. bersabda:

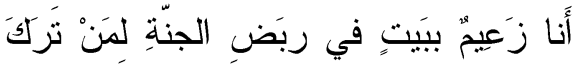

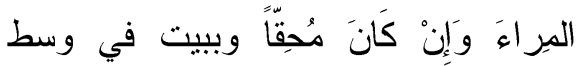

$$
\begin{aligned}
& \text { الجنة لمن ترك الكذب و إن كان مازحا. }
\end{aligned}
$$

Oleh karena itu, penyiaran tidak boleh berlebihan dalam mengkritik pihak lain baik pribadi maupun lembaga, karena kesalahan merupakan sesuatu yang mesti ada, sebagaimana Sabi Muhammad Saw bersabda: (كل بني dan sikap berlebihan ini bisa mebuat lari para penerimanya. Oleh karena itu, seorang penggiat penyiaran tidak dibenarkan untuk membeberkan kesalahan pihak lain dengan cara merendahkan dan sesukanya. 
Adapun proporsinal dan adil keduanya adalah karakteristik dari metodologi Islam. Sedangkan penyiaran Islam adalah yang seharusnya lebih melaksanakan keduanya dalam pemberitaannya. Oleh karena itu, penyiaran Islam berkomitmen dengan keadilan dan keseimbangan dalam segala keadaan, tidak boleh berpihak kepada individu, strata, ras, atau kepada kepentingan materi dengan menjual hak. Allah berfirman dalam Al-Qur'an Surat Al-Maidah Ayat 6, sehingga hati seorang penggiat penyiaran muslim, dasar tsaqafah-nya dan jiwanya senantiasa membela perkataan yang hak meskipun dirayu dengan harta, politik, dan tekanan sosial. Maka rasa muraqabatullah lah yang dapat mewujudkan kesuksesan penyiaran seiring dengan gagalnya pengawasan administratif, dewan pers, dan tim pencari fakta. $^{27}$

\section{Penyiaran yang Realistis dan Berkembang}

Materi penyiaran Islam mengacu kepada realita dan senantiasa mengikuti fenomena-fenomena sosial yang mengajak kepada kebaikan dan sebaliknya mengecam segala bentuk

\footnotetext{
${ }^{27}$ Ibrahim Imam. (1985). hlm. 49-50.
}

keburukan dan senantiasa menyuguhkan solusi dengan metode fleksibel dan jelas tujuannya. Dalam hal ini program pengembangan untuk meningkatkan kemajuan dan kebangkitan umat selaras dengan metode ilmiah yang terencana dengan rapi yang mengacu kepada riset dan kajian-kajian strategis, sebagaimana hal ini terus berupaya untuk sampai kepada revolusi teknologi dalam bentuk inovasi dan kreasi. Inilah penyiaran Islam yang sesungguhnya dan berjalan di jalur yang luas sekaligus memanfaatkan saluran-saluran satelit dan jaringan internet.

\section{Penyiaran yang Komprehensif, Global, dan Komunikatif}

Penyiaran ini menangani persoalan kehidupan manusia secara keseluruhan yang seolah-olah menyeru umat seluruhnya yang mengacu kepada kesempurnaan Islam (Q.S. Al-Nahl Ayat 89) dan (Al-An'am Ayat 38) yang mencakup problem politik, ekonomi, dan sosial. Dan juga memperhatikan ilmu, adab, dan pandangan-pandangan kontemporer di masyarakat Islam di tengah-tengah mengikuti kabar harian, kejadian-kejadian yang silih berganti, dan pengalaman-pengalaman yang sedang terjadi, yang semua itu 
ditimbang dengan prinsip manhaj, maka apa-apa yang selaras dengan Islam diterima, dan apa-apa yang menyelisihinya, maka hal itu ditolak. Oleh karena itu, dalam hal memberi solusi terkait permasalahan yang terjadi haruslah sesuai dengan yang diatur oleh agama setelah diteliti dengan metode ilmiah yang sedetil mungkin, karena dapat berpengaruh kepada masyarakat dan dapat menggiring pendapat (ide) secara umum. ${ }^{28}$

Islam adalah pesan global untuk seluruh umat manusia, Allah berfirman (Q.S. A-Anbiya' Ayat 107), maka ini berarti penyiarannya juga harus ditujukan kepada penduduk alam semesta, dan hal ini yang mendorong untuk mewujudkan kemajuan yang luar biasa dalam penyiaran dan sarananya yang masih terbatas pada jarak, waktu, dan ruang. Dengan demikian, sesuai dengan keunggulan penyiaran Islam serta prinsipnya, akan tetapi tetap komunikatif tidak mengasingkan diri dari pihak lain dan bahkan memperpanjang jembatan kerjasama dan mengambil faedah (khususnya teknologi dan selama akademik)

\footnotetext{
${ }^{28}$ Ibrahim Imam. (1985). hlm. 53.
}

bersama lembaga-lembaga yang lainnya.

\section{Penyiaran Positif dan Konstruktif}

Yakni bertujuan untuk memperbaiki para penerima (masyarakat) dengan menggunakan retorika dalam pengarahannya yang mampu mengalirkan maklumat dari hal yang dapat menembus ideologi dan intelektual, mengotori identitas keislaman, dan menyebarkan tradisi Barat yang diusung oleh sistem globalisasi. Sebagaimana penyiaran Islam juga berperan untuk membekali masyarakat dengan berita-berita dan maklimat yang berguna yang membantu mereka dalam rangka memakmurkan bumi, mengerahkan segala energi, dan meningkatkan kehidupan yang tinggi dengannya.

Penyiaran Islam bukan hanya cermin dari realita yang memantulkan apa yang ada di dalamnya, akan tetapi penyiaran yang merupakan qiyadah (komando), hiburan, keluhuran, pembaharuan, dan pembangunan. ${ }^{29}$ Dan juga bagi penyiaran Islam, bukanlah hanya sebagai sarana untuk berekspresi saja (al-ta'bir), tapi juga untuk

\footnotetext{
${ }^{29}$ Ibrahim Imam. (1985). hlm. 53.
} 
mengadakan perubahan (al-taghyir). Dan di antara fungsi yang paling dominan adalah memuaskan masyarakat dengan perubahan (revolusi) pemikiran dan tingkah laku. Karean penyiaran tidak hanya menyampaikan berita dan maklumat, akan tetapi bertujuan untuk merubah tingkah laku masyarakat menjadi lebih baik. ${ }^{30}$ Zain Al-'Abidin Al-Rikabi berkata: "Al-Balagh al-mubin memiliki tiga unsur: al-taushil (menyampaikan), al-ta'rif (memberitahukan), dan al-iqna' (memuaskan). Ketiga unsur ini meliputi prinsip dasar penyiaran modern, yaitu komunikasi, pengendalian, menyiarkan maklumat, dan argumen yang logis.”,31

\section{Kaidah Penyiaran dalam Islam}

Penulis telah menyampaikan sebelumnya bahwa terdapat similiarity antara dakwah, komunikasi dan dakwah. Abdul Muis berpendapat bahwa penyiaran dalam Islam adalah sebagai bidang kajian Ilmu Dakwah yang menjadi core values dengan perspektif Islamnya. ${ }^{32}$ Sehingga kaidah-

\footnotetext{
53.

30 Al-Ghulayaini. Wasa'il Al-Ilam. hlm.

31 Muhammad Al-Nadwah Al-Alawiyah. (1979). Al-I'lam Al-islami wa Al-'Alaqat AlInsaniyyah. Riyadh: Al-Mulazhamah. hlm. 300.

32 A Muis. (2001). Komunikasi Islami Penyiaran. Bandung: PT Remaja Rosdakarya.
}

kaidahnya pun tidak jauh berbeda dengan ilmu dakwah. Dakwah adalah ajakan atau seruan kepada seseorang atau sekelompok orang untuk mengikuti dan mengamalkan nilai-nilai dan ajaran Islam. Bagi yang belum Islam diajak untuk menjadi muslim, dan bagi yang sudah Islam diajak untuk menyempurnakan keislamannya. ${ }^{33}$

Menurut Muhammad Al-Bahiy, penyiaran Islam berarti merubah suatu situasi ke situasi yang lebih baik sesuai ajaran Islam. penyiaran memiliki dua dimensi, yaitu penyampaian pesan kebenaran yang isinya mengenai dimensi kerisalahan dan dimensi kedua mencakup pengaplikasian nilai kebenaran yang merupakan dimensi kerahmatan. $^{34}$ Untuk itu dapat disimpulkan bahwa unsur-unsur penting penyiaran yang harus diperhatikan adalah:

a. penyiaran harus diberikan ( $\bar{l} s h a \bar{l} l)$ dan disampaikan (tablīgh) kepada masyarakat luas, Allah S.W.T. berfirman:

33 Andy Darmawan, dkk. (2002). Metodologi Ilmu Dakwah. Yogyakarta: Lesfi. hlm. 24.

34 Asep Kusnawan. (2004). Komunikasi dan Penyiaran Islam. Bandung: Benang Merah Pres. hlm. 7. 
"Dan sesungguhnya telah Kami turunkan berturut-turut perkataan ini (Al-Qur'an) kepada mereka agar mereka mendapat pelajaran.” (Q.S.

Al-Qashash [28]: 51).

"Wahai orang yang berkemul (berselimut), bangunlah, lalu berilah peringatan!" (Q.S. AlMuddatstsir [74]: 1-2)

b. Penyiaran harus diemban oleh pelaku atau lembaga yang memiliki kompetensi (mu'ahhal), karenanya Allah S.W.T. pun memujinya.

Allah S.W.T. berfirman:

"Dan siapakah yang lebih baik perkataannya daripada orang yang menyeru kepada Allah, mengerjakan amal shaleh, dan berkata: 'Sesungguhnya aku termasuk orang-orang yang berserah diri?" (Q.S. Fushshilat [41]: 33).

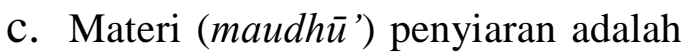
ajaran Islam, mencakup akidah, syari'ah, ibadah, mu'amalah, akhlak, prinsip, aturan dan kaedah Islam yang menjamin kebahagiaan hidup di dunia dan akhirat. Allah S.W.T. berfirman:

"Sesungguhnya agama (yang diridhai) di sisi Allah hanyalah Islam...” (Q.S. Ali 'Imran [3]: 19).

"Barangsiapa mencari agama selain Islam, maka sekali-kali tidaklah akan diterima (agama itu) dari padanya, dan ia di akhirat termasuk orang-orang yang rugi." (Q.S. Ali 'Imran [3]: 85).

d. Penyiaran ditujukan atau diserukan kepada para masyarakat, yaitu seluruh umat manusia tanpa kecuali, yang memiliki beragam tipologi, baik suku bangsa, ras, warna kulit maupun berdasarkan klasifikasi kemanusiaan lainnya.

Allah S.W.T. berfirman:

"Katakanlah: 'Wahai manusia, sesungguhnya aku adalah utusan Allah kepada kalian semua..." (Q.S. Al-A'raf [7]: 158).

Dan Kami tidak mengutusmu, melainkan kepada umat seluruh manu-sia sebagai pembawa berita gembira dan sebagai pemberi peringatan, tetapi kebanyakan manusia tiada mengetahui." (QS. Saba' [34]: 28).

Rasulullah S.A.W. bersabda:

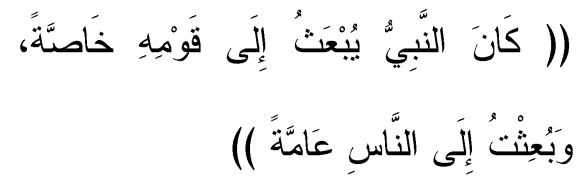

"Nabi (terdahulu) diutus hanya kepada kaumnya saja, sedangkan aku diutus kepada seluruh umat manusia." (H.R. Al-Bukhārī, Muslim, Al-Nasā'̄i dan Ahmad)

e. Penyiaran harus difondasikan dengan asas dan prinsip yang benar, yaitu berdasarkan Al-Qur'an dan asSunnah, serta berlandaskan kepada 
pemahaman para sahabat Nabi S.A.W. dan generasi Salaf yang mengikuti mereka.

f. Penyiaran harus mengusung tujuan yang benar, yaitu jalan Allah S.W.T. yang diperintahkan-Nya dalam firman-Nya:

Katakanlah: 'Inilah jalan (agama)ku, aku dan orang-orang yang mengi-kutiku mengajak (kalian) kepada Allah dengan hujjah yang nyata, Maha suci Allah, dan aku tidak termasuk orang-orang yang musyrik." (Q.S. Yusuf [12]: 108).

Jalan (sabill) penyiaran tersebut adalah jalan yang telah ditempuh oleh para sahabat Rasulullah S.A.W. dan juga orang-orang sesudahnya, yaitu al-salaf al-shāleh dari umat ini.

g. Penyiaran dikelola oleh pelaku atau lembaga yang menjadi pengemban dakwah tersebut; dimana ketika berdakwah ia harus selalu memperhatikan tipologi masyarakat yang beraneka ragam.

Untuk itu penyiaran memiliki peran penting dalam merealisasikan teori kredo atau syahadah di maksyakat luas.

Allah S.W.T. berfirman:

"Dan hendaklah ada di antara kalian segolongan umat yang menyeru kepada kebajikan, menyuruh kepada yang ma'ruf dan mencegah dari yang munkar; merekalah orangorang yang beruntung." (Q.S. Ali 'Imran [3]: 104)

Rasulullah S.A.W. bersabda:

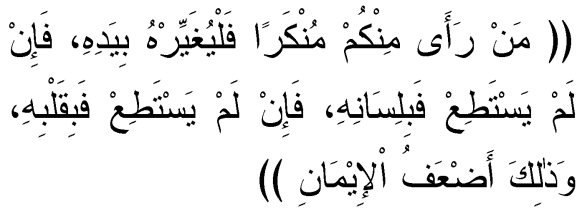

"Barangsiapa di antara kalian yang melihat kemunkaran, maka rubahlah dengan tangannya. Bila ia tidak mampu, maka rubahlah dengan lisannya. Dan bila ia tidak mampu juga, maka rubahlah dengan hatinya, karena hal tersebut merupakan manifestasi keimanan yang paling lemah." (H.R. Muslim, Al-Tirmidz̄, Ibnu Mājah dan Al-Nasā'ī)

Ibnu Katsīr berkata:

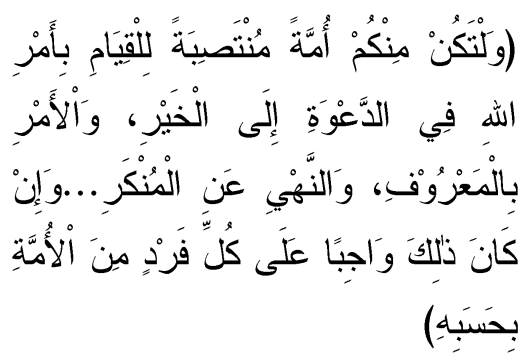

"Maksudnya, hendaklah ada di antara kalian segolongan umat yang menyiap-kan dirinya untuk mengemban perintah Allah dalam mendakwahkan keba-jikan, memerintahkan yang ma'ruf dan melarang dari kemunkaran... Perintah tersebut merupakan kewajiban setiap individu umat sesuai dengan kemam- 
puannya masing-masing

(fardhu kifāyah)., 35

Namun banyak pula ulama yang mensintesakan bahwa hukum dakwah ada-lah fardhu 'ain bagi setiap Muslim, di antaranya Imam Abu Bakar AlJashshash, ${ }^{36}$ Al-Fakhr Al-Razi ${ }^{37}$ dan 'Abdul Karim Zaidan ${ }^{38}$, karena "min" dalam ayat tersebut berfungsi sebagai klarifikasi penjelasan ( $l i$ al-tabyīn), bukan mewajibkan kepada sebagiannya saja (li al-tab'ìdh). ${ }^{39}$

35 Ismā'īl bin 'Umar bin Katsīr AlDimasyqī. (2004). Tafsīr Al-Qur'ān Al-'Azhìm (Tafsīr Ibn Katsīr), ed. Syāmī bin Muhammad Salāmah. Riyadh: Dār Thayyibah. hlm. 91 .

${ }^{36}$ Abū Bakar Ahmad bin 'Alī Al-Rāzī Al-Jashshāsh. (t.t.). Ahkām Al-Qur'ān, ed. 'Abd Al-Salām Muhammad 'Alī Syāhīn. Beirut: Dār Al-Kutub Āl-'Ilmiyyah. hlm. 37-38.

37 Al-Fakr Al-Rāzī. (t.t.). Al-Tafsīr AlKabìr. Beirut: Dār Ihyā' Al-Turāts Al-'Arabī. hlm. 166.

${ }^{38}$ Zaidān. Ushūl Al-Da'wah. hlm. 299.

39 'Abdullah bin Wakil Al-Syaikh berpandangan, bahwa yang wajib bagi kaum Muslimin adalah menyampaikan (faridhah albalāgh), karena mereka adalah umat pengemban risalah dan yang ber-kewajiban mendakwahkannya (ummah risālah wa da'wah). Demikian pula pandangan Prof. Dr. Abu Zahrah, yang menyatakan bahwa dalam dakwah ada dua kewajiban, yaitu kewajiban umum dan kewajiban khusus. Kewajiban umum adalah kewajiban setiap orang dalam berdakwah kepada Islam, memberikan petunjuk dan berita yang menggembirakan, hukumnya fardhu 'ain. Adapun kewajiban khusus yang hukum-nya fardhu kifāyah adalah adanya tenaga ahli yang khusus dari umat untuk mendakwah-kan Islam tersebut. : 'Abdullah bin Wakīl Al-Syaikh. Ta 'ammulāt Da 'wiyyah. hlm. 45-48 dan 69; dan Abu Zahrah. (1994). Dakwah Islamiah. Bandung: PT Remaja Rosdakarya. hlm. 49-53.

\section{Metode Penyiaran dalam Islam}

Penyiaran Islam sebagai bidang kajian Ilmu Dakwah yang menjadi core values dengan perspektif Islamnya. Hal ini menjadi selaras dengan visi jurusan Komunikasi dan Penyiaran Islam yaitu terde-erdepan dalam pengkajian dan pengembangan ilmu-ilmu komunikasi dan penyiaran Islam yang berparadigma Islam. Secara terperinci metode dakwah dalam Al-Qurean terekam pada surat An-Nahl ayat 125, yaitu: hikmah, pelajaran yang baik dan mujadalah.

Hal tersebut dapat diambil pemahaman bahwa metode dakwah itu meliputi tiga cakupan. Moh. Ali Aziz dalam bukunya Ilmu Dakwah secara garis besar tiga cakupan metode dakwah, yaitu:

\section{a. Hikmah}

Berdakwah dengan memperhatikan situasi dan kondisi sasaran dakwah dengan menitikberatkan pada kemampuan-kemampuan mereka, sehingga di dalam menjalankan ajaranajaran Islam selanjutnya, mereka tidak lagi merasa terpaksa atau keberatan. Sebagai metode dakwah, hikmah diartikan bijaksana, akal budi yang mulia, dada yanglapang, hati yang bersih, dan menarik perhatian orang kepada agama dan Tuhan. Menurut 
Imam Abdullah bin Ahmad Mahmud An-Nasafi dalam buku Metode Dakwah karya M. Munir, mengartikan hikmah, yaitu:

"Dakwah bil-hikmah" adalah dakwah dengan menggunakan perkataan yang benar dan pasti, yaitu dalil yang menjelaskan kebenaran dan menghilangkan keraguan.

Dari pengertian tersebut, M. Munir mengartikan hikmah merupakan kemampuan dan ketepatan da'i dalam memilih, memilah dan menyelaraskan teknik dakwah dengan kondisi objektif mad'u.

\section{b. Mauizhāh Hasanah}

Terminologi mauizhaah hasanah dalam perspektif dakwah sangat populer. Istilah mauizhaah hasanah terdiri dari dua kata, mauizhaah dan hasanah. Kata mauizhaah berarti nasihat, bimbingan, Pendidikan dan peringatan, sementara hasanah merupakan kebalikan dari sayyi'ah yang artinya kebaikan lawan kejelekan. Mauizhaah hasanah yaitu berdakwah dengan memberikan nasihat-nasihat atau menyampaikan ajaran-ajaran Islam yang disampaikan itu dapat menyentuh hati mereka.

Menurut Imam Abdullah bin Ahmad Mahmud An-Nasafi dalam buku
Metode Dakwah karya M. Munir, mengartikan Mauizhaah Hasanah, yaitu: al-Mauizhaah al-Hasanah" adalah (perkataan perkataan) yang tidak tersembunyi bagi mereka, bahwa engkau memberikan nasehat dan menghendaki manfaat kepada mereka atau dengan al-Qur'an. Sedangkan menurut M. Munir sendiri, pengertian dari Mauizhaah Hasanah adalah katakata yang masuk ke dalam perasaan dengan penuh kelembutan, tidak membongkar atau membeberkan kesalahan orang lain, sebab kelemahlembutan dalam menasehati seringkali dapat meluluhkan hati yang keras dan menjinakkan qalbu yang liar.

\section{c. Mujādalah}

Mujadalah adalah berdakwah dengan cara bertukar pikiran dan membantah dengan cara yang sebaikbaiknya dengan tidak memberikan tekanan-tekanan kepada sasaran dakwah.55

Menurut Imam Abdullah bin Ahmad Mahmud An-Nasafi dalam buku Metode Dakwah karya M. Munir, mengartikan Mauizhaah Hasanah, yaitu:

"Berbantahan yang baik yaitu dengan jalan yang sebaikbaiknya dalam bermujadalah, 
antara lain dengan perkataan yang lunak, lemah lembut, tidak dengan ucapan yang kasar atau dengan mempergunakan sesuatu (perkataan) yang bisa menyadarkan hati, membangunkan jiwa dan menerangi akal pikiran, ini merupakan penolakan bagi orang yang enggan melakukan perdebatan dalam agama.

Dari pengertian tersebut, M. Munir mengartikan mujadalah merupakan tukar pendapat yang dilakukan oleh dua pihak secara sinergis, yang tidak melahirkan permusuhan dengan tujuan agar lawan menerima pendapat yang diajukan dengan memberikan argumentasi dan bukti yang kuat.

\section{KESIMPULAN}

Agama Islam sudah mengatur masalah penyiaran melalui aturanaturan dakwah. ${ }^{40}$ Prinsip yang mendasar adalah informasi yang disiarkan haruslah memiliki otentisitas dan validitas sumber dan kebenarannya. Berita atau informasi yang tidak akurat merupakan bentuk pelanggaran berat. ${ }^{41}$ Sederhananya dalam Islam, penyiaran harus berpijak pada sumber informasi yang benar serta memberikan

\footnotetext{
${ }^{40}$ Q.S. Ali-Imran: 20 dan An-Nahl: 82.

${ }^{41}$ Q.S. Ar-Ra'ad: 40.
}

kemashlahatan agama dan dunia. ${ }^{42}$ Sebab berita apapun, dapat mengandung kebenaran, dapat pula mengandung kesalahan (al-khabār yahtamilu ashshidq wa al-kidzb), kecuali berita dari Allah Ta'ala dan hadist Rasulullah Shalallhu 'alaihi wa sallam yang shahih. ${ }^{43}$ Prinsip penyiaran bertolak pada prinsip hukum Islam itu sendiri, yaitu; (1) Prinsip tauhid, (2) Prinsip keadilan atau keseimbangan (al-mizān), (3) Prinsip amr ma'rūf nahyi munkar, (4) Prinsip kebebasan dan kemerdekaan (al-hurriyyah), (5) Prinsip persamaan atau egaliterianisme (al-musawah), (6) Prinsip tolong menolong (al-ta'āwun), dan (7) Prinsip toleransi (al-tasāmuh). ${ }^{44}$ Prinsip tauhid memberikan pengertian bahwa penilaian baik-buruk suatu penyiaran sepatutnya didasarkan pada kriteria dari Tuhan Yang Maha Esa, sebab Pembukaan UUD 1945 telah menegaskan, bahwa negara Republik Indonesia berdasar atas Ketuhanan Yang Maha Esa yaitu Allah Ta'ala. Meyakini, bahwa penyebaran informasi punya tanggung jawab dunia dan akhirat. Prinsip

${ }^{42}$ Q.S. Al-Hujurat: 6-8.

43 Faris Khoirul Anam, http://www. republika.co.id/Jurnalislamia/diposting 7 Maret 2015.

44 Juhaya. S. Praja. Filsafat Hukum Islam. hlm. 69, 72, 75, 76, dan 77. 
keadilan dan persamaan mengharuskan penyiaran memberikan porsi yang seimbang dalam memberikan informasi. Islam perintah berlaku adil ditujukan kepada setiap orang tanpa pandang bulu. Perkataan yang benar harus disampaikan apa adanya walaupun perkataan itu akan merugikan kerabat sendiri. Keharusan berlaku adil pun harus ditegakkan dalam keluarga dan masyarakat muslim itu sendiri, bahkan kepada orang kafir pun umat Islam diperintahkan berlaku adil. Untuk keadilan sosial harus ditegakkan tanpa membedakan karena kaya miskin, pejabat atau rakyat jelata, wanita atau pria, mereka harus diperlakukan sama dan mendapat kesempatan yang sama. ${ }^{45}$ Prinsip kemerdekaan dan amr ma'ruf nahyi munkar dalam penyiaran menjamin kebebasan membuat dan menyebarkan informasi mencakup kebebasan berfikir, berbicara, dan mengungkap sesuatu. Pengungkapan suatu peristiwa, atau pendapat, dapat diekspresikan melalui lisan (oral), pena, atau tindakan (action). Kebebasan berbicara atau transfer informasi akan terwujud setelah kebebasan berfikir terjamin. Dalihnya, ucapan ataupun tindakan pasti terlahir

45 Juhaya S. Praja. (1993). Filsafat Hukum Islam. hlm. 73. dari suatu refleksi atau pemikiran. Oleh karena itu, kebebasan membuat dan menyebarkan informasi, terkait dengan dua bentuk kebebasan lainnya, yaitu kebebasan berfikir dan kebebasan mengeluarkan pendapat (mengekspresikan pendapat dan kritik).

\section{DAFTAR PUSTAKA}

\section{Sumber dari Jurnal}

Elo, S. et.al. (2014). Qualitative Content Analysis: A Focus on Trustworthiness. SAGE Open January-March, 4.

Mirzaqon, T.A. dan Purwoko, B. Library Research of The Basic Theory and Practice of Expressive Writing Counseling. Jurnal Nasional.

Praja, J.S. (1993). Filsafat Hukum Islam. Islamic Law.

Sarbini, M. dan Maya, R. (2019). Gagasan Pendidikan Anti Jahiliyah dan Implementasinya. Edukasi Islami: Jurnal Pendidikan Islam, 08(01).

Zaini, Z.D. (2011). Implementasi Pendekatan Yuridis Normatif dan Pendekatan Normatif Sosiologis dalam Penelitian Ilmu Hukum. Journal Article Pranata Hukum.

\section{Sumber dari Buku}

Aḥmad bin 'Alī Al-Rāzī Al-Jashshāsh, A.B. (t.t.). Ahkām Al-Qur'ān, ed. 'Abd Al-Salām Muhammad 'Alī Syāhīn. Beirut: Dār Al-Kutub Al'Ilmiyyah. 
Al-Alawiyah, M.A. (1979). Al-I'lam Alislami wa Al-'Alaqat Al-Insaniyyah. Riyadh: Al-Mulazhamah.

Al-Fath Al-Bayanuni, M. (1993). AlMadhal Ila 'Ilmi Al-Da'wah, Beirut: Mu'asasah Al-Risalah.

Al-Rāzī, A. (t.t.). Al-Tafsìr Al-Kabìr. Beirut: Dār Ihyā' Al-Turāts Al'Arabī.

Al-Shallaby, A.M. (2005). Al-Sirah AlNabawiyyah wa tahlil Ahdats. Beirut: Dar Al-Ma'rifah.

Bin Katsīr Al-Dimasyqī̄, I.U. (2004). Tafsīr Al-Qur'ān Al-'Azhīm (Tafsìr Ibn Katsīr), ed. Syāmī bin Muhammad Salāmah. Riyadh: Dār Thayyibah.

Darmawan, A., dkk. (2002). Metodologi Ilmu Dakwah. Yogyakarta: Lesfi.

Hisyam, I. (t.t.). Al-Sirah AlNabawiyyah, Juz 2. Beirut: Dar AlFikri.

Imam, I. (1985). Ushul Al-I'lam Al-Islami. Kairo: Dar Al-Fikri.

Katsir, A.I. (1988). Al-Bidayah wa AlNihayah. Bairut: Maktabah AlMa'arif, Juz 4.

Kusnawan, A. (2004). Komunikasi dan Penyiaran Islam. Bandung: Benang Merah Pres.

Maulana, M.S. (1403 H). Al-Mas'uliyyah Al-I'lamiyyah. Kairo: Maktabah AlKhaniji.

Mufid, M. (2007). Komunikasi dan Regulasi Penyiaran. Jakarta: Kencana Prenada Media Group.
Muis, A. (2001). Komunikasi Islami Penyiaran. Bandung: PT Remaja Rosdakarya.

Qutb, S. (2002). Tafsir fi Dzilalli AlQur'an. Jakarta: Gema Insani Press.

Suhandang, K. (2013). Ilmu Dakwah. Bandung: PT Remaja Rosdakarya.

Praja, J.S. (1993). Filsafat Hukum Islam.

Thasy, A.Q. (1990). Idha'at Haula Al-I'lam Al-Islami. Qatar: Micistay Fawqaf and Islamic Affers.

Thayibah, R.M. (1984). Al-Huquq wa AlHurri Al-Siyasah fi Al-Syarah AlIslamiyah. Wasington: Ma'had Alili Al-Fikr Al-Islami.

Wahf Al-Qaḥthānī, S.A. (1994). Muqawwimāt Al-Dā'iyah Al-Nājih fi Dhau' Al-Kitāb wa Al-Sunnah: Mafhūm wa Nazhar wa Tathbīq. Saudi Arabia: tp.

Zaenudin, J. (2015). Metode dan Strategi Penerapan Syari'at Islam di Indonesia. Jakarta: Pembela Islam Penyiaran.

Zahrah, A. (1994). Dakwah Islamiah. Bandung: PT Remaja Rosdakarya.

Zaidān, A.A. (2005). Ushūl Al-Da'wah. Beirut: Mu'assasah Al-Risālah Nāsyirūn.

\section{Sumber Internet}

Faris Khoirul Anam, http://www. republika.co.id/Jurnalislamia, diposting tanggal 7 Februari 2015. 